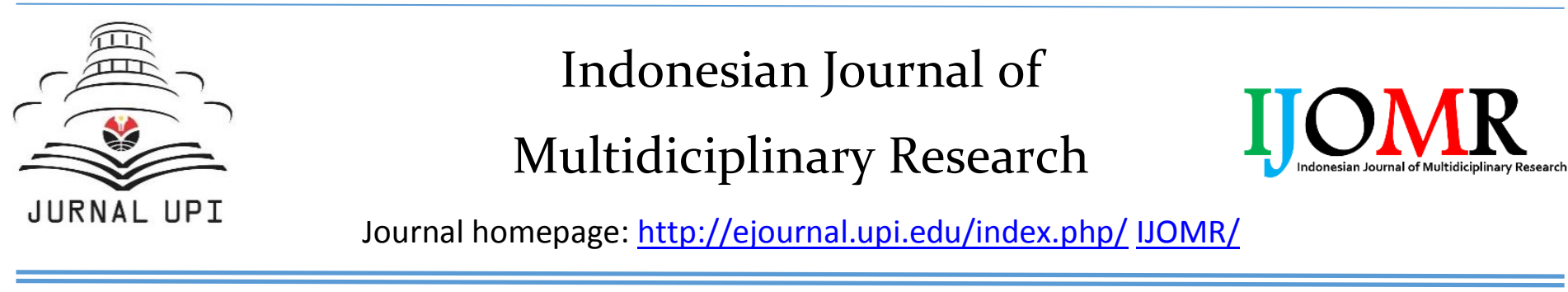

\title{
Electrical Analysis of Combination of Orange Peel and Tamarind for Bio-battery Application as an Alternative Energy
}

\author{
Aghisna Nuthfah Anshar, Aldi Maulana, Siti Nurazizah, Zalfa Nurjihan, Sri Anggraeni , Asep Bayu Dani \\ Nandiyanto \\ Universitas Pendidikan Indonesia, Bandung 40154, Indonesia \\ Correspondence: E-mail: aghisnanutfhfah@upi.edu, aldimaul@upi.edu, sitinurazizah@upi.edu, \\ zalfanurjihan@upi.edu
}

\begin{abstract}
A B S T R A C T S
The use of disposable primary batteries causes environmental pollution due to the lack of battery waste treatment facilities, so it is necessary to handle the problem by making bio-batteries from orange peel and tamarind. The purpose of this study is to know the influence of good electricity on variations of the combination of orange peel and tamarind. The novelty of this study is (1) the use of biomass combination of orange peel and tamarind as biobattery electrolytes and (2) comparison of orange peel to tamarind. The method used in this study is by experimenting with a mixture of sweet orange peel and tamarind made into pasta and put in a used battery. The results showed that biobatteries with a variation of $25 \%$ orange to tamarind had the highest voltage and the most powerful electric current. This happens because the ion content in the variation is not concentrated so it is easy to move widely. In conclusion, biobatteries with a mixture of orange peel and acid are the best variation of $25 \%$ orange peel against tamarind. The study is expected to reduce the use of chemicals in batteries and reduce disposable battery waste.
\end{abstract}

\begin{tabular}{l}
\hline A R T I C L E I N F O \\
\hline Article History: \\
Submitted/Received 30 Jan 2021 \\
First revised 10 Feb 2021 \\
Accepted 11 Feb 2021 \\
First available online 11 Feb 2021 \\
Publication date 01 Mar 2021 \\
\hline Keyword: \\
Alternative energy, \\
Bio-battery, \\
Electricity, \\
Orange peel, \\
Tamarind.
\end{tabular}

ART ICLE INFO

Article History:

Submitted/Received 30 Jan 2021

First available online 11 Feb 2021

Publication date 01 Mar 2021

Alternative energy,

Tamarind. 


\section{INTRODUCTION}

The use of disposable primary batteries can cause pollution to the environment due to the lack of means of treating waste from used batteries so that they end up in the trash (Widyaningsih \& Mulud, 2017). One of the efforts to reduce this pollution is by making biobatteries (Ratnawati, et al., 2010). Bio-battery is a device that generates electrical energy from materials derived from living things. Fruits are among the ingredients with the greatest potential to be used as bio-batteries (Fauzia, et al., 2019). Orange peels (Salafa, et al., 2020) and tamarind (Suciyati \& Supriyanto, 2019) have high electrolyte content, so they can be used as electrolytes in batteries.

Several studies on bio-batteries have been conducted including bio-batteries from Durio zibenthinus peels (Febriyanto, et al., 2019), coconut pulp (Zhang, et al., 2016), bananas (Hotang, et al., 2018), Terminalia cattapa (Yan \& Saha, 2012), as well as oranges and orange peels (Fauzia, et al., 2019). However, there has not been found a study using a combination of orange peel and tamarind as an electrolyte in the bio-battery.

The purpose of this study was to determine the effect of good electricity on the variation of the combination of orange peel and tamarind for bio-battery. The method used is to crush the orange peel and tamarind until it becomes a paste, mix it according to the variations, and put it in a used battery. The novelty of this research are (1) the use of a combination of biomass of orange peel and tamarind as bio-battery electrolyte and (2) the ratio of orange peel to tamarind.

\section{METHODS}

Figure 1 is the process of making a bio-battery using an experimental method. The materials used in this research were orange peel, tamarind, carbon sticks, and used 1.5 volt batteries. Orange peel and tamarind crushed into a paste. After that, the two ingredients are mixed. The variations in the combination of orange peel against tamarind used were 0,25 , 50,75 , and $100 \%$. Then, put into a used battery that has been cleaned.

\section{RESULTS AND DISCUSSION}

\subsection{Voltage}

Figure 2 is the result of the voltage test from the variation of orange peel and tamarind ratio. The test results showed that the highest voltage was obtained by the variation of orange peel with a percentage of $25 \%$, namely 1.7 volts, while the lowest was obtained from variations in orange peels with a percentage of $100 \%$, namely 1.43 volt. Changes in the variation of the peel of orange and tamarind affect the voltage (Erviana, et al., 2020) because the ions gather in adhering to the cathode so that the amount of charge flows from anode to cathode. The more ions collected, the higher the voltage generated (Atina, 2015).

\subsection{Electric Current}

Based on the results of observations of electric currents from the variation in the percentage of orange peel to tamarind shown in Table 1. The results showed that the highest value of electric current was owned by the variation of orange peel with a percentage of $25 \%$, namely $1.33 \mathrm{~mA}$, while the lowest value was owned by the variation of orange peel with a percentage of $0 \%$, namely 0.63 . In the variation of $0 \%$ orange peel has the meaning that the content of $100 \%$ tamarind that indicates variations of tamarind in the paste very 
concentrated, this density results in the content of ions produced very tight and crowded so that the existing ions are difficult to move and produce a small electric current, while in the variation of $25 \%$ of existing ions have a wide movement so that it is easy to move because of the decrease in density obtained from orange peel (Fadillah, 2019). The value of this current is influenced by the amount of voltage and resistance in the battery (Abidin, et al., 2020).

\section{CONCLUSION}

The ratio of orange peel to tamarind has an influence on the magnitude of the voltage and the strength of the electric current. The best bio-battery is when the percentage of orange peel to tamarind was $25 \%$.

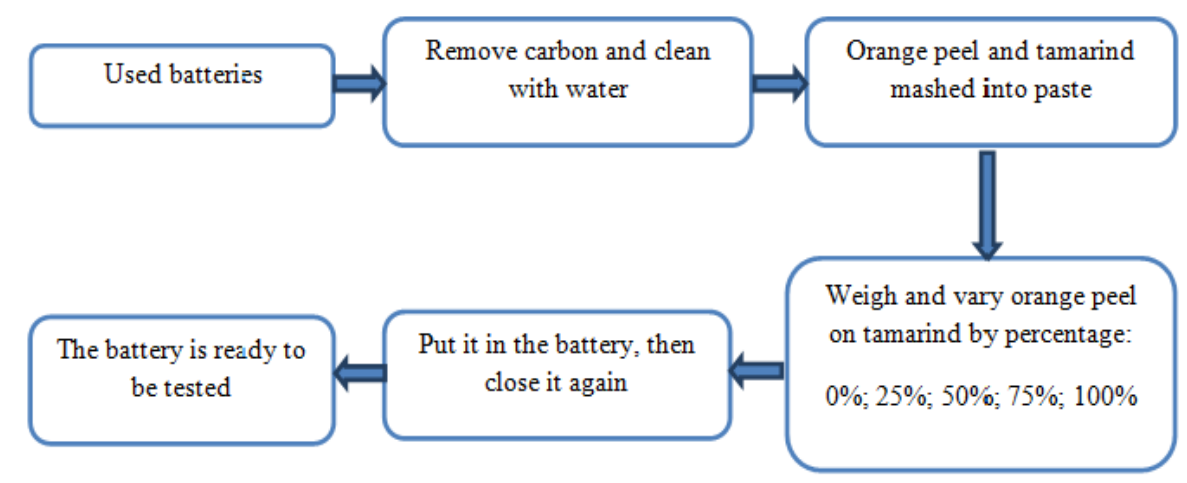

Figure 1. The process of making orange peel and tamarind bio-battery

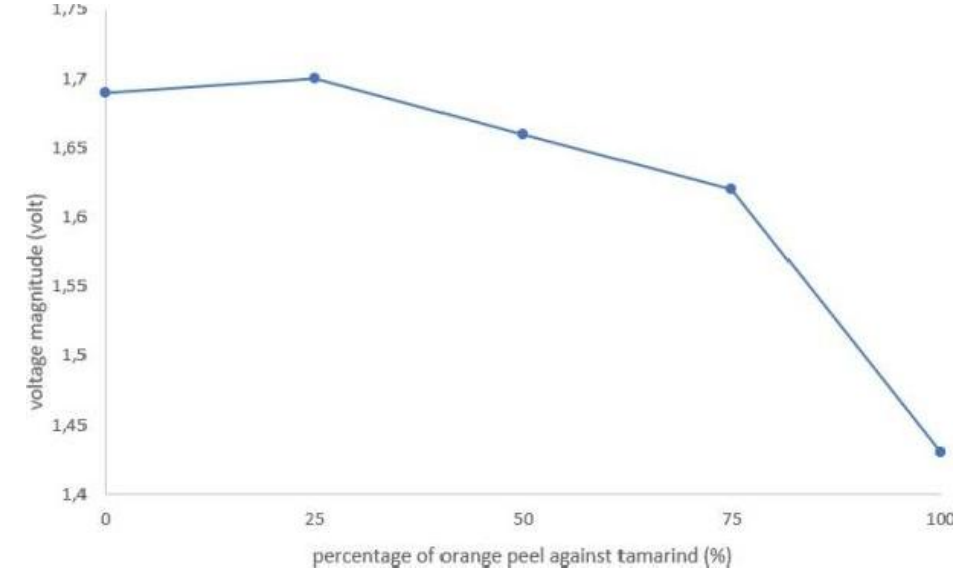

Figure 2. Voltage of percentage of orange peel against tamarind

Table 1. Electric current from the varitation in the percentage of orange peel against tamarind

\begin{tabular}{cc}
\hline $\begin{array}{c}\text { Percentage of orange peel } \\
\text { against tamarind (\%) }\end{array}$ & Electric Current (mA) \\
\hline $\mathbf{0}$ & 0.62 \\
$\mathbf{2 5}$ & 1.33 \\
$\mathbf{5 0}$ & 0.92 \\
$\mathbf{7 5}$ & 0.95 \\
$\mathbf{1 0 0}$ & 1.20 \\
\hline
\end{tabular}




\section{AUTHORS' NOTE}

The author states that there is no conflict of interest regarding the publication of this article. The author confirms that the paper is free from plagiarism. There are still many shortcomings and need further research from this article so that the resulting battery is used like a conventional battery.

\section{REFERENCES}

Abidin, M., Hafidh, A. F., Widyaningsih, M., Yusuf, M., and Murniati, A. (2020) Pembuatan Biobaterai berbasis ampas kelapa dan tomat busuk. Al-Kimiya: Jurnal Ilmu Kimia dan Terapan, 7(1), 28- 34.

Atina, A. (2015). Tegangan dan kuat arus listrik dari sifat asam buah. Sainmatika: Jurnal Ilmiah Matematika dan IImu Pengetahuan Alam, 12(2), 28-42.

Erviana, Y., Supriyanto, A., Suciyati, S. W., and Pauzi, G. A. (2020). Analisis karakteristik elektrik onggok singkong fermentasi yang diawetkan sebagai pasta bio-baterai. Journal of Energy, Material, and Instrumentation Technology, 1(1), 27-32.

Fadillah, M. (2019). Pengaruh kepekatan larutan elektrolit asam jawa (tamarindus indica) terhadap kelistrikan sel volta. In Seminar Nasional Lontar Physics Forum. 37-41.

Fauzia, S., Ashiddiqi, M. A. H., and Khotimah, A. W. I. K. (2019). Fruit and vegetables as a potential source of alternative electrical energy. Proceeding International Conference on Science and Engineering, 2, 161-167.

Febriyanto, P., Jerry, J., Satria, A. W., and Devianto, H. (2019). Pembuatan dan karakterisasi karbon aktif berbahan baku limbah kulit durian sebagai elektroda superkapasitor. Jurnal Integrasi Proses, 8(1), 19-24.

Hotang, R. R., Sarwuna, D., Munfaatun, E. S., and Togibasa, O. (2018). Pengaruh kandungan glukosa terhadap arus listrik pada biobaterai dari pasta elektrolit ketapang (terminalia catappa L.), Jurnal Fisika Flux: Jurnal IImiah Fisika FMIPA Universitas Lambung Mangkurat, 15(2), 110-116.

Ratnawati, E., Ermawati, R., and Naimah, S. (2010). Teknologi biosorpsi oleh mikroorganisme, solusi alternatif untuk mengurangi pencemaran logam berat. Jurnal Kimia dan Kemasan, 32(1), 34-40.

Salafa, F., Hayat, L., and Ma'ruf, A. (2020). An analysis of orange peel (citrus sinensis) as the material for electrolytes in bio-batteries. Jurnal Riset Rekayasa Elektro, 2(1), 1-9.

Suciyati, S. W., and Supriyanto, A. (2019). Analisis jeruk dan kulit jeruk sebagai larutan elektrolit terhadap kelistrikan sel volta. Jurnal Teori dan Aplikasi Fisika, 1, 7-16.

Widyaningsih, W. P., and Mulud, T. H. (2017). Analisis pemanfaatan limbah kulit pisang sebagai energi alternatif pada baterai. Journal Eksergi, 13(2).

Yan, R., and Saha, T. K. (2012). Voltage variation sensitivity analysis for unbalanced distribution networks due to photovoltaic power fluctuations. IEEE Transactions on Power Systems, 27(2), 1078- 1089.

Zhang, Y., Gao, Z., Song, N., and Li, X. (2016) High-performance supercapacitors and batteries derived from activated banana-peel with porous structures. Electrochimica Acta, 222, 1257-1266. 